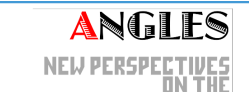

ANELOPHONE WORLD

\section{Angles}

New Perspectives on the Anglophone World

$8 \mid 2019$

Neoliberalism in the Anglophone World

\title{
Changes in Official Poverty and Inequality Rates in the Anglophone World in the Age of Neoliberalism
}

\section{Nicholas Sowels}

\section{(2) OpenEdition}

12 Journals

\section{Electronic version}

URL: https://journals.openedition.org/angles/560

DOI: $10.4000 /$ angles.560

ISSN: 2274-2042

\section{Publisher}

Société des Anglicistes de l'Enseignement Supérieur

\section{Electronic reference}

Nicholas Sowels, "Changes in Official Poverty and Inequality Rates in the Anglophone World in the Age of Neoliberalism", Angles [Online], 8 | 2019, Online since 01 April 2019, connection on 06 June 2022. URL: http://journals.openedition.org/angles/560 ; DOI: https://doi.org/10.4000/angles.560

This text was automatically generated on 6 June 2022.

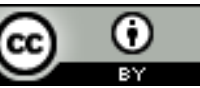

Angles est mise à disposition selon les termes de la Licence Creative Commons Attribution 4.0 International. 


\title{
Changes in Official Poverty and Inequality Rates in the Anglophone World in the Age of Neoliberalism
}

\author{
Nicholas Sowels
}

1 This article presents an overview of official poverty and inequality rates in the Anglophone world, which are key issues related to the emergence of neoliberal capitalism since the late 1970s. They have had an important role to play in the rise of populist political movements leading to protectionist and nationalist politics, especially in the United States and the United Kingdom (Gamble 2017). In both countries, neoliberalism and globalization have left significant sections of society behind, fuelling popular anger against the status quo and so-called metropolitan elites, especially since the financial crisis and Great Recession. The Brexit referendum in June 2016 and the election of Donald Trump in November 2016 are clear manifestations of such anger in the face of public policies that have largely pursued a back-to-business agenda since the crisis.

2 The rise of inequality has been especially strong in the United States, where the "top $1 \%$ " of rich households has demonstrably pulled away from the rest of society in terms of income growth and wealth accumulation. Meanwhile, "middle America" has been largely left out of the growth that has accompanied neoliberal economic policies that go back to the 1970s, as a way of tackling stagflation at the time. Broadly speaking, these policies have included significant reductions in direct government intervention in economies and the strengthening of market forces to make product, financial and labour markets more flexible. Specifically, policies have been based on: the abandonment of fiscal policy as a tool for managing demand and supporting employment in favour of monetary policy aimed primarily at achieving low inflation, steep tax cuts for top income earners, the deregulation of markets, the privatization and contracting out of public service provision, the deliberate weakening of trade union power, the pursuit of international trade liberalization, and the financialization of the world economy which has been in the forefront of globalization. Such policies 
have varied from country to country, as has their impact on inequality and poverty levels in the industrialized world. But among the developed countries, these policies have been especially pronounced in the Anglophone world, and they contrast strongly with the more interventionist policies of government that shaped capitalism in the post-war era.

3 To examine the broader impact of neoliberalism on poverty and inequality, this article will begin by providing a brief overview of the definitions of both phenomena which are linked but distinct. Section 2 will then present the key basic data on inequality and poverty trends, using standardized data provided by the OECD. It will also provide summary statistics concerning the income share of the "top 1\%" provided by the World Inequality Database, constructed by the team of researchers working with Thomas Piketty. ${ }^{1}$ The final section will review and analyze the specificity of the Anglophone world's experience with neoliberalism.

\section{Key definitions of poverty and inequality}

Poverty and inequality are linked but separate phenomena and affect the lives of millions of people on a daily basis in the Anglophone world (and beyond). Before turning to the dry statistics, it is important to recall - I believe - that the daily hardship of poverty is lost in the data and is generally absent in the media, and even in art. We may be exposed to war and terror on TV, while the audio-visual and plastic arts can shock. Abject poverty is also easily visible on the streets of major cities, where homeless people and refugees huddle under shelters, in cardboard boxes or simple tents. But most of the time, the daily grind of, say, the 40 million US citizens living below the poverty line takes place out of sight. Only occasionally it is captured on film, in TV documentaries, or in written fiction.

\section{Measuring poverty}

5 There are two traditional definitions of poverty which split the Anglophone world. The first definition is more politically conservative and is based on assigning an absolute monetary value to poverty. This approach is used in the United States, where a poverty threshold is calculated on the basis of a "dollar amount for the sum of three broad categories of basic goods and services - food, clothing, and shelter (including utilities)" (Citro and Michael 1995). The poverty threshold is then adjusted to take into account household composition, with successive adults and children being weighted less in terms of the resources they need. Thus, in 2017, the poverty threshold for persons living in mainland America (i.e. not Alaska nor Hawaii) was a yearly income of $\$ 12,750$ for a single adult under the age of 65 , and $\$ 24,858$ for a household with two adults under 65, and two children under 18 (see Table 1) (US Census Bureau 2018).

6 The other principle definition of poverty is a relative definition. Used in the European Union and by international organizations such as the OECD, this definition sets the poverty threshold at 60 (or 50) percent of the median household disposable income, equivalised to take into account household composition. This means that all state benefits/transfers are first added to households' initial earned income and taxes are subsequently deducted. Again, adults in a household have diminishing weights, as do children. ${ }^{2}$ 
7 Poverty - or "low income" - is usually measured like this in the United Kingdom. Government statistics however also use an absolute definition of poverty/low income. This is calculated by adjusting the 60 percent median income threshold in a base year (currently 2010/11) for inflation, to provide a more absolute measure of poverty (McGuinness 2018). Relative measures of poverty by definition follow the evolution of median wages. By contrast, this calculation of absolute poverty in real money terms increases more slowly, as it does not reflect real growth in the economy, only price increases. In an expanding economy, this leads to more visible falls in poverty. An important issue in the UK statistics (and in other Anglophone countries) is also the inclusion or not of housing costs. Given the slow growth of housing units in recent decades in the UK, housing is an increasingly pressing expense on household budgets. As a result, the percentage of people living on low income "after housing costs" (AHC) is about 5 percentage points higher than the share on low income "before housing costs" (BHC).

In Ireland, the official measure of poverty relates to "consistent poverty", which draws on two overlapping indicators: i) the at-risk-of-poverty indicator of individuals living in households below 60 percent of the median income, and ii) the basic deprivation indicator which captures individuals lacking 2 or more of 11 basic necessities, which include two pairs of shoes, a warm waterproof overcoat, new (not second-hand) clothes, the ability to eat a meal with meat, chicken or fish (or the vegetarian equivalent) every second day, and have a roast joint or equivalent once a week, the ability to keep adequately warm, etc. (Dept. of Employment Affairs and Social Protection 2016).

Table 1: Monetary Values of Poverty Thresholds (and equivalent in euros $\left.{ }^{\star}\right)^{3}$

\begin{tabular}{|l|l|l|l|l|}
\hline & Indicator & Year & $\begin{array}{l}\text { Income per } \\
\text { year, 1 person }\end{array}$ & $\begin{array}{l}\text { Income per year, 2 } \\
\text { adults \& 2 children }\end{array}$ \\
\hline $\begin{array}{l}\text { United } \\
\text { States }\end{array}$ & $\begin{array}{l}\text { Poverty line (absolute value: } \\
\text { basket of goods and services) }\end{array}$ & 2017 & $\begin{array}{l}\$ 12,750 \\
(€ 9,960)\end{array}$ & $\begin{array}{l}\$ 24,858 \\
(€ 20,209)\end{array}$ \\
\hline $\begin{array}{l}\text { United } \\
\text { Kingdom }\end{array}$ & $60 \%$ median income BHC & $2016 / 17$ & $\begin{array}{l}€ 17,200 \\
(€ 19,770)\end{array}$ & $\begin{array}{l}(€ 36,000 \\
(€ 40,900)\end{array}$ \\
\hline Ireland & $60 \%$ median income & & $€ 12,358$ & $€ 25,823$ \\
\hline Canada & LIM (Low income measure) & 2015 & $\begin{array}{l}C \$ 22,133 \\
(€ 14,097)\end{array}$ & $\begin{array}{l}\mathrm{C} \$ 44,266 \\
(€ 28,194)\end{array}$ \\
\hline Australia & $60 \%$ median income BHC & $2013-14$ & $\begin{array}{l}\mathrm{A} \$ 26,600 \\
(€ 16,729)\end{array}$ & $\begin{array}{l}\mathrm{A} \$ 55,862 \\
(€ 35,133)\end{array}$ \\
\hline
\end{tabular}




\begin{tabular}{|l|l|l|l|l|}
\hline $\begin{array}{l}\text { New } \\
\text { Zealand }\end{array}$ & $60 \%$ median income BHC & 2016 & $\begin{array}{l}\text { NZ\$22,620 } \\
(€ 13,464)\end{array}$ & $\begin{array}{l}\text { NZ\$49,400 } \\
(€ 29,404)\end{array}$ \\
\hline
\end{tabular}

Sources: (full references are given at the end of the article): US: Census Bureau, "Poverty Thresholds", 2018; UK: DWP, "Households Below Average Income: An analysis of the UK income distribution: 1994/95-2016/17"; Ireland: European Anti Poverty Network Ireland, "Relative Poverty Rates"; Canada: Statistics Canada, "Census in Brief: Children living in low-income households"; Australia: Australian Council of Social Service [ACOSS] and Social Policy Research Centre [SPRC], "Poverty in Australia 2016"; New Zealand: Ministry of Social Development, "Household incomes in New Zealand: Trends in indicators of inequality and hardship 1982 to $2016 "$.

9 Canada has no official poverty line. A number of low income lines are nevertheless used by government agencies to inform public debate. Thus, Statistics Canada formulated the Low Income cut-offs (LICO) in the 1960s. These are thresholds below which families that spend more than 20 percentage points than the average family on certain necessities are defined as having a low income. The necessities include food, shelter and clothing. This is a low, but relative definition of poverty. The Market basket measure (MBM) in contrast defines a family as having a low income if it does not have enough money to buy "a specific set of goods and services that represent a basic standard of living". The MBM is therefore an absolute measure of poverty, similar to the US poverty line. Lastly, Canada also uses a Low income measure (LIM) which identifies families with income below the $50 \%$ median household income. This is similar to the EU definition - but lower. In 2014, it was estimated that $8.8 \%$ of the population (3.0 million people) were living below the LICO; $11.3 \%$ (or 3.9 million) below the MBM rate, and 13.0\% (4.5 million) below the LIM (Government of Canada 2016). The relative definition using the $50 \%$ of median income threshold therefore seems to be the broadest, most inclusive definition.

Australia has no official definition of a poverty threshold either. Instead, poverty is principally measured by two independent, non-governmental organizations, albeit using public data. The Melbourne Institute tracks an absolute measure of poverty. This is done by updating a benchmark of weekly disposable income for a family of two adults and two children, as originally calculated in December 1973 (at A\$62.70). Other thresholds for different types of families are calculated using equivalence scales: there seems to be no calculation for isolated individuals. These poverty lines are updated using an index of per capita household disposable income. Thus, in September 2017, the poverty line for this two-adult, two-child household was $\mathrm{A} \$ 961.21$ per week, including housing costs, and A $\$ 744.07$ other than housing (Melbourne Institute 2018). For its part, the Australian Council of Social Service and the Social Policy Research Centre regularly report on relative poverty lines at the $50 \%$ and $60 \%$ of median disposable household income, before and after housing costs. For a couple with two children, the poverty line in 2013-14 at the $60 \%$ threshold was A $\$ 1,074.27$ BHC and A\$864.26 AHC (ACOSS and SPRC 2016).

Lastly, New Zealand also uses a mix of absolute and relative measures. Thus, two relative thresholds are calculated at " 50 and 60 percent of the current year's household disposable income median net-of-housing-costs". An absolute measure is also calculated, based on $50 \%$ of the 2007 median household income (net-of-housing-costs), which has been subsequently updated to ensure its real value (Ministry of Social Development 2017). 


\section{Defining inequality}

12 Measures of inequality typically relate mainly to income. The two most common measures are the Gini coefficient which is derived from the Lorenz Curve and the ratio of the top $10 \%$ (or $20 \%$ ) of incomes to the bottom $10 \%$ (or $20 \%$ ) of incomes. The Gini coefficient provides a scale indicator of inequality running from 0 (or $0 \%$ ) indicating total equality, to 1 (or 100\%) indicating total inequality (in which the top $1 \%$ takes all). It is usually used for income inequality, where statistics tend to be more reliable as they are usually based on households' tax declarations.

Some qualifying comments need to be made about this, however. There are limits to the upper-most value of the Gini coefficient concerning the distribution of income, simply because all members of a society need to receive some income to ensure subsistence, otherwise a society (or community) will collapse. Also, as societies get richer, the quantity of basic necessities needed to function in society - and the economy - rises. As a result, Gini coefficients have historically never exceeded 0.6 in today's major industrialized nations (including in the $19^{\text {th }}$ century) (Milanovic 2016). In the post-World War II period and even with the rise of neoliberalism, Gini coefficients for disposable household income (after benefits and taxes) tend to cluster in a relatively narrow range from $0.25-0.3$ for fairly equal societies (as in Scandinavia), to 0.35-0.4 for unequal societies (as in the United States today). It is only in extremely unequal societies, where national income is sufficiently higher than total, national subsistence income, that higher Gini values of 0.45 and more may be found (typically in Latin America).

14 The Gini coefficient may also be used to indicate wealth inequality. This however is less common because estimating wealth inequality is hard: declarations are less frequent (for example inheritance tax declarations) and wealth may often be held more in families than by individuals. Moreover, holders of wealth frequently avoid declaring assets fully, which is also the case for incomes. As a result, Gini coefficients are generally likely to understate inequalities.

\section{An Overview of Current Poverty Rates and Inequality Trends in the Anglophone Countries}

Table 2 is taken from the OECD Income Distribution and Database (IDD). It provides two indicators of poverty: a relative measure at the $50 \%$ threshold of median disposable income; and a more absolute measure: the "anchored" 50\% threshold of median disposable income in 2005 uses the same procedure to adjust for inflation as described for the UK and New Zealand above. The Table ranks poverty rates for 2015 in ascending order.

Not surprisingly, the United States comes nearly bottom of the list, just behind Turkey, with 17.2 percent of its population living in poverty, based on this measure compared to $13.5 \%$ of the population living below the official poverty line in 2015 (Semega et al. 2017: 43). Canada too has a poverty level that was above the OECD average: respectively 14.2 percent and 11.6 percent in 2015. In diminishing order, Australia (12.8 percent), New Zealand (10.9 percent) and the United Kingdom (also at $10.9 \%$ ) are clustered around the OECD average. Only Ireland, with a poverty rate of 9.2 
percent, has a significantly lower rate, more akin to the rates found in continental and northern Europe. A quick glance at the table does indeed provide some impression of loose country groupings. Thus, the emerging countries (Turkey, Mexico and Chile) have significantly higher poverty rates than the OECD average. By contrast, poverty rates in the Scandinavian countries (Denmark, Finland, Iceland, Norway and Sweden) are all lower - sometimes much lower - than the OECD average. Northern European countries (the Netherlands, Austria, Germany and Belgium) along with France are also all situated around the OECD average. On the other hand, the Mediterranean countries (Portugal, Italy, Greece and Spain) all had above-average poverty rates in 2015. Finally, the Central European countries have relatively low poverty rates, which is not the case for the Baltic States of Estonia and Latvia - Lithuania is not a member of the OECD but with 16.5 percent, it has a similar poverty rate to its Baltic neighbors.

This broad breakdown corresponds in general terms to the image one has of the different welfare states and "varieties of capitalism" in the developed world (see below). Poverty rates are lower on average in the more equal societies in Scandinavia, followed by countries with traditionally strong welfare states in northern Europe. In contrast, countries with more limited welfare states in the Mediterranean also have higher rates of poverty on the whole. As for the Anglophone countries, they stand out collectively as having liberal welfare states, with minimal state income support for pensions and unemployment pay, which are backed up by private welfare schemes. The US stands out strongly as having a very high poverty rate by OECD standards.

Table 2: Poverty Rates in the OECD Countries

\begin{tabular}{|c|c|c|c|c|c|c|c|c|c|c|c|c|}
\hline \multirow{3}{*}{$\begin{array}{c}15 \text { December } 2017 \\
\text { Updated countries } \\
\text { and values are } \\
\text { shaded }\end{array}$} & \multicolumn{9}{|c|}{ Poverty rate (relative threshold: $50 \%$ median disposable income) } & \multicolumn{3}{|c|}{$\begin{array}{l}\text { Poverty rate (threshold } \\
\text { "anchored" in 2005) }\end{array}$} \\
\hline & & & Total & & & age gro & , latest & ivailable y & & & Total & \\
\hline & 2007 & & 2014 & 2015 or & Children & Youth & Adult & Elderly & Working & 2007 & 2014 & 2015 or \\
\hline Denmark & 5,9 & e & 5,4 & 5,5 & 2,9 & 21,6 & 4,0 & 3,2 & 4,0 & $4,7 \mathrm{e}$ & 4,7 & 4,6 \\
\hline Finland & 7,8 & & 6,8 & 6,3 & 3,7 & 18,1 & 5,5 & 5,2 & 4,0 & 6,4 & 4,6 & 4,3 \\
\hline Czech Republic & 5,5 & & 5,9 & 6,4 & 10,5 & 6,6 & 5,7 & 4,2 & 3,9 & 3,4 & 3,6 & 3,2 \\
\hline Iceland & 6,6 & & 4,5 & 6,5 & 7,2 & 8,5 & 6,1 & 5,4 & 6,0 & 3,7 & 4,5 & 6,9 \\
\hline Netherlands & 6,5 & e & 7,7 & 7,9 & 10,2 & 19,7 & 6,2 & 3,7 & 6,1 & $5,6 \mathrm{e}$ & 6,1 & 6,2 \\
\hline Luxembourg & 7.1 & & 8,3 & 8,1 & 11,3 & 9,9 & 7,5 & 3,9 & 7,6 & 7,0 & 8,9 & 8,4 \\
\hline France & 7,5 & e & 8,1 & 8.1 & 11,3 & 13,9 & 7,4 & 3,1 & 7.1 & .. & 7,3 & 7.1 \\
\hline Norway & 7,8 & & 8.1 & 8,1 & 7,3 & 24,1 & 6,3 & 4,4 & 6,4 & & 4,4 & 4,4 \\
\hline Slovak Republic & 6,8 & & 8,7 & 8,4 & 14,8 & 8,2 & 7,5 & 3,4 & 5,9 & 3,4 & 3,3 & 2,9 \\
\hline Austria & 9,7 & & 9,0 & 8,7 & 9,6 & 11,4 & 8,2 & 7,8 & 6,6 & 9,7 & 8,4 & 8,2 \\
\hline Slovenia & 7,9 & & 9,4 & 9,2 & 7,0 & 7,9 & 8,8 & 13,5 & 5,9 & 6,1 & 8,5 & 8,3 \\
\hline Sweden & 8,4 & e & 9,0 & 9,2 & 9,1 & 12,1 & 7,7 & 11,4 & 5,2 & & 3,2 & 2,8 \\
\hline Ireland & 9,6 & & 8,8 & 9,2 & 9,2 & 14,7 & 8,8 & 6,8 & 3,5 & 7,2 & 14,2 & 11,4 \\
\hline Germany & 9,0 & & 9,1 & 9,5 & 9,5 & 14,7 & 8,8 & 9,4 & 3,7 & 8,8 & 8,6 & 8,6 \\
\hline Belgium & 9,2 & & 9,1 & 9,8 & 11,0 & 10,3 & 9,4 & 9,5 & 4,5 & 8,3 & 7,1 & 6,8 \\
\hline Switzerland & 9,7 & e & 8,6 & 9,9 & 9,9 & 9,3 & 7,2 & 19,4 & 7,1 & & 6,9 & 7,5 \\
\hline Hungary & 6,4 & e & 10,3 & 10,1 & 11,8 & 11,9 & 9,6 & 8,6 & 7,2 & & 13,0 & 9,1 \\
\hline United Kingdom & 12,8 & & 10,5 & 10,9 & 11,2 & 10,6 & 9,9 & 13,8 & 5,9 & 11,8 & 9,5 & 9,0 \\
\hline New Zealand & 11,0 & e & 9,9 & 10,9 & 14,1 & 9,6 & 9,8 & 10,5 & 6,6 & $5,5 \mathrm{e}$ & 5,7 & 5,6 \\
\hline Poland & 9,6 & & 10,4 & 11,1 & 13,4 & 12,1 & 10,8 & 8,5 & 8,4 & 5,2 & 3,6 & 3,2 \\
\hline OECD & 11,5 & e & 11,7 & 11,6 & 13,1 & 13,7 & 10,1 & 12,9 & 8.0 & $8.5 \mathrm{e}$ & 9,7 & 9,4 \\
\hline Portugal & 12,8 & & 13,5 & 12,6 & 15,5 & 14,1 & 12,0 & 10,8 & 9,0 & 10,8 & 13,8 & 11,8 \\
\hline Australia & 14,9 & e & 14,0 & 12,8 & 13,0 & 8,0 & 10,6 & 25,7 & 4,8 & & 8,2 & 7,1 \\
\hline Italy & 11,9 & & 13,3 & 13,7 & 19,3 & 15,5 & 13,4 & 9,3 & 12,4 & 10,6 & 15,6 & 16,3 \\
\hline Korea & 14,8 & e & 14,4 & 13,8 & 7,1 & 7,9 & 8,6 & 45,7 & 5,6 & $14,4 \mathrm{e}$ & 11,4 & 10,9 \\
\hline Canada & 12,9 & & 12,6 & 14,2 & 17,1 & 17,3 & 13,5 & 10,7 & 11,0 & 11,3 & 9,0 & 9,6 \\
\hline Greece & 13,2 & & 14,8 & 14,9 & 18,9 & 18,8 & 15,6 & 7,7 & 13,1 & 11,3 & 33,6 & 33,2 \\
\hline Spain & 14,2 & & 15,3 & 15,3 & 22,1 & 21,0 & 15,3 & 5,9 & 14,8 & 14,2 & 22,5 & 21,9 \\
\hline Estonia & 13,8 & & 15,5 & 16,1 & 12,1 & 13,1 & 12,8 & 31,9 & 8,8 & 4,3 & & \\
\hline Chile & 17,8 & & 16,8 & 16,1 & 21,1 & 15,1 & 13,9 & 16,3 & 13,8 & 14,0 & 7,8 & 6,4 \\
\hline Japan & 15,7 & e & 16,0 & 16,1 & 16,3 & 19,7 & 13,8 & 19,0 & 13,3 & & 19,6 & 17,2 \\
\hline Latvia & 18,6 & & 16,2 & 16,2 & 12,2 & 9,9 & 13,5 & 30,9 & 8,5 & 5,2 & 4,9 & 4,3 \\
\hline Mexico & 18,4 & e & 18,9 & 16,7 & 19,7 & 12,0 & 14,4 & 25,6 & 15,3 & $13,3 \mathrm{e}$ & 16,0 & 14,7 \\
\hline United States & 17,4 & e & 17,5 & 16,8 & 19,9 & 18,4 & 14,1 & 20,9 & 11,0 & .. & 19,3 & 17,6 \\
\hline Turkey & 17,0 & e & 17,3 & 17,2 & 25,3 & 15,5 & 13,0 & 17,0 & 15,5 & & 6,8 & 5,2 \\
\hline
\end{tabular}

Source: OECD Income Distribution Database (IDD). Gini, poverty, income, Methods and Concepts. http:// www.oecd.org/social/income-distribution-database.htm 
18 Table 2 also shows that with relative poverty at the $50 \%$ threshold, the impact of the 2007-2008 financial crisis and ensuing Great Recession has been largely absorbed in the Anglophone world. The figures for 2015 indicate that relative poverty rates are now lower than in 2007, with the notable exception of Canada, where this measure of the poverty rate rose from 12.9 percent in 2007 to 14.2 percent in 2015. Canada's figures are comparatively high in terms of the OECD average, and their increase has been substantial.

At the same time, Canada and the UK have seen quite clear falls in the percentage of persons living at or under the "anchored" threshold (in the UK, this percentage fell from 11.8 percent in 2007 to 9.4 percent in 2015). Other things being equal, fewer people are therefore living in poverty in real terms, indicating that the effects of the financial crisis have been mitigated to some degree. In Canada, this likely stems from the fact that the financial crisis had far less impact on its banking system, and so on growth. In the UK, government measures to protect pensions mean that incomes of older people were safeguarded after the crisis. This probably explains much of the reduction in "anchored" poverty, though it should be noted that young people have been particularly badly affected by the crisis. The measure of "anchored" poverty is also particularly telling for Ireland. While Ireland too has seen a fall in the percentage of persons living under the $50 \%$ threshold, the share of persons living at or under the "anchored" rate actually increased from 7.2 percent in 2007 to 11.4 percent in 2015, reflecting the huge economic shock experienced by Ireland due to the financial crisis (Whelan 2013).

Table 3: Inequality Indicators for the OECD countries (Gini coefficient and ratio of top 20 percent to bottom 20 percent) ${ }^{4}$

\begin{tabular}{|c|c|c|c|c|c|c|c|c|c|c|c|c|}
\hline \multirow{2}{*}{\begin{tabular}{|c|}
15 December 2017 \\
$\begin{array}{c}\text { Updated countries } \\
\text { and values are } \\
\text { shaded }\end{array}$
\end{tabular}} & & & & \multicolumn{4}{|c|}{ Gini coefficient } & \multirow[b]{2}{*}{\begin{tabular}{|c} 
Increase \\
1980 to \\
2015
\end{tabular}} & \multicolumn{4}{|c|}{ S80/S20 income share ratio } \\
\hline & $1980^{*}$ & 1985 & 1995 & 2007 & & 2014 & $\begin{array}{c}2015 \text { or } \\
\text { latest } \\
\text { available } \\
\text { year }\end{array}$ & & 2007 & & 2014 & $\begin{array}{c}2015 \text { or } \\
\text { latest } \\
\text { available } \\
\text { year }\end{array}$ \\
\hline Iceland & & & & 0,286 & & 0,241 & 0,246 & & 4,1 & & 3,4 & $\frac{y e a l}{3,6}$ \\
\hline Slovenia & & & & 0,239 & & 0,251 & 0,250 & & 3,5 & & 3,7 & 3,7 \\
\hline Slovak Republic & & & & 0,245 & & 0,247 & 0,251 & & 3,5 & & 3,7 & 3,7 \\
\hline Denmark & 0,255 & 0,221 & 0,215 & 0,244 & e & 0,254 & 0,256 & 0,001 & 3,4 & e & 3,6 & 3,6 \\
\hline Czech Republic & & & & 0,256 & & 0,257 & 0,258 & & 3,6 & & 3,7 & 3,7 \\
\hline Finland & 0,217 & $0,209(86)$ & 0,22 & 0,269 & & 0,257 & 0,260 & 0,043 & 3,9 & & 3,7 & 3,7 \\
\hline Belgium & 0,226 & & & 0,277 & & 0,266 & 0,268 & 0,042 & 4,1 & & 3,9 & 4,0 \\
\hline Norway & 0,235 & $0,222(86)$ & 0,243 & 0,250 & | & 0,257 & 0,272 & 0,037 & 3,7 & I & 3,9 & 4,1 \\
\hline Austria & $0,266(83)$ & & & 0,284 & & 0,274 & 0,276 & 0,010 & 4,4 & & 4,1 & 4,2 \\
\hline Sweden & 0,2 & $0,198(83)$ & 0,211 & 0,259 & e & 0,274 & 0,278 & 0,078 & 3,9 & e & 4,1 & 4,2 \\
\hline Luxembourg & & $0,247(86)$ & & 0,277 & & 0,280 & 0,284 & & 4,0 & & 4,2 & 4,2 \\
\hline Hungary & & & 0,294 & 0,271 & e & 0,289 & 0,288 & & 3,9 & e & 4,5 & 4,5 \\
\hline Germany & 0,251 & 0,251 & 0,266 & 0,285 & & 0,292 & 0,289 & 0,038 & 4,3 & & 4,4 & 4,4 \\
\hline Poland & & & & 0,316 & & 0,298 & 0,292 & & 5,0 & & 4,7 & 4,6 \\
\hline France & 0,291 & & & 0,292 & e & 0,293 & 0,295 & 0,004 & 4,3 & e & 4,4 & 4,4 \\
\hline Korea & & & & 0,312 & e & 0,302 & 0,295 & & 5,6 & e & 5,4 & 5,1 \\
\hline Switzerland & 0,303 & & & 0,298 & e & 0,295 & 0,297 & $-0,006$ & 4,6 & e & 4,4 & 4,6 \\
\hline Ireland & 0,311 & & & 0,304 & & 0,308 & 0,298 & $-0,013$ & 4,6 & & 4,8 & 4,6 \\
\hline Netherlands & 0,248 & 0,272 & 0,297 & 0,308 & e & 0,305 & 0,303 & 0,055 & 4,6 & e & 4,6 & 4,6 \\
\hline OECD & & & & 0,318 & e & 0,316 & 0,317 & & 5,5 & e & 5,5 & 5,5 \\
\hline Canada & 0,282 & 0,293 & 0,289 & 0,317 & & 0,313 & 0,318 & 0,036 & 5,3 & & 5,2 & 5,5 \\
\hline Italy & 0,291 & $0,291(84)$ & 0,327 & 0,313 & & 0,325 & 0,326 & 0,035 & 5,2 & & 5,8 & 5,9 \\
\hline Japan & 0,244 & 0,304 & 0,323 & 0,329 & el & 0,336 & 0.330 & 0,086 & 6,0 & el & 6.2 & 6,1 \\
\hline Estonia & & & & 0,313 & & 0,346 & 0,330 & & 5,2 & & 6,2 & 5,8 \\
\hline Portugal & 0,224 & & & 0,361 & & 0,338 & 0,336 & 0,112 & 6,3 & & 5,9 & 5,8 \\
\hline Australia & 0,269 & & 0,309 & 0,338 & e & 0,326 & 0,337 & 0,068 & 5,8 & e & 5,5 & 5,7 \\
\hline Greece & $0,33(81)$ & $0,352^{\star}$ & & 0,329 & & 0,339 & 0,340 & 0,010 & 5,6 & & 6,4 & 6,4 \\
\hline Spain & 0,318 & & & 0,324 & & 0,344 & 0,345 & 0,027 & 5,2 & & 6,6 & 6,5 \\
\hline Latvia & & & & 0,374 & & 0,350 & 0,346 & & 7,3 & & 6,4 & 6,3 \\
\hline Israel & & 0,326 & 0,338 & 0,365 & e & 0,360 & 0,346 & & 7,5 & e & 7,1 & 6,5 \\
\hline New Zealand & 0,281 & 0,272 & 0,335 & 0,330 & e & 0,333 & 0,349 & 0,068 & 5,3 & e & 5,3 & 5,8 \\
\hline United Kingdom & 0,267 & 0,309 & $0,337(94)$ & 0,373 & & 0,356 & 0,360 & 0,093 & 6,6 & & 6,0 & 6,1 \\
\hline United States & 0,304 & & $\begin{array}{r}0,361 \\
\end{array}$ & 0,374 & $\mathrm{e}$ & 0,394 & 0,390 & 0,086 & 7,9 & $\mathrm{e}$ & 8,7 & 8,3 \\
\hline Turkey & & & & 0,409 & e & 0,398 & 0,404 & & 7,8 & e & 7,7 & 7,8 \\
\hline Chile & & & & 0,480 & & 0,465 & 0,454 & & 11,8 & & 10,6 & 10,0 \\
\hline Mexico & & $0,452(84)$ & & 0,450 & e & 0,457 & 0.459 & & 10.8 & e & 11,5 & 10.4 \\
\hline
\end{tabular}

Source: OECD Income Distribution Database (IDD). Gini, poverty, income, Methods and Concepts. http:// www.oecd.org/social/income-distribution-database.htm 

indicates that Ireland had a slightly more equal income distribution on this measure in 2015 than the OECD average (respectively 0.298 and 0.317). This distinguishes Ireland from the other Anglophone countries. Canada at 0.318 was only a little more unequal, followed by Australia at 0.337 . For New Zealand, the Gini coefficient was 0.349 , while the UK was at 0.360 and the US at 0.390 . The high Gini coefficients of these last four countries - Australia, New Zealand, the UK the US - are strong manifestations of the rise in inequality associated with neoliberalism in the Anglophone world. In all cases, the Gini coefficient rose substantially from 1980 (roughly the beginning of neoliberal tax cutting policies) to 2015: up by 0.068 in both Australia and New Zealand, by fully 0.093 in the United Kingdom and by 0.086 in the United States. It should be noted however that these increases were not uniform. In particular, reviewing global inequality trends in 2017, François Bourguignon distinguishes countries like the United States (as well as France, Denmark and Sweden, Israel and Japan) which have experienced a rising inequality trend, from those which have been characterized by a "one-step" rise. The latter include the United Kingdom and New Zealand (where inequality rose strongly in the second half of the 1980s, and then remained largely unchanged before actually falling somewhat after the financial crisis), and Canada and Australia (both experiencing their one-step increase in the second half of the 1990s, and again small drops in the immediate years after the crisis) (Bourguignon 2017).

the Anglophone countries (and elsewhere) is based on looking at the share of income going to the top 1\% of households. Data from the World Inequality Database show very clearly how the pretax national income share of the Top $1 \%$ has risen since 1980, when neoliberal policies began taking effect (see Table 4). This follows the long "great compression" of inequality in the middle of the $20^{\text {th }}$ century (discussed in the next section). The income share going to the top $1 \%$ of households has increased strongly in the Anglophone countries, especially in the UK (up from 6.67 percent of all income in 1981 to 13.88 percent in 2014) and in the United States (up from 10.67 percent in 1980 to 20.2 percent in 2014).

Table 4: Pre-Tax National Income Share of Top 1\%

\begin{tabular}{|l|l|l|l|l|}
\hline & 1920 & 1950 & 1980 & 2014 \\
\hline Australia & $11.63(1921)$ & 14.13 & 4.57 & 9.1 \\
\hline Canada & 14.40 & 10.88 & 8.88 & $13.6(2010)$ \\
\hline France & 20.07 & 10.34 & 8.17 & 10.80 \\
\hline
\end{tabular}




\begin{tabular}{|l|l|l|l|l|}
\hline Ireland & $16.93(1938)$ & $12.92(1943)$ & 6.65 & $10.50(2009)$ \\
\hline New Zealand & $11.34(1921)$ & 9.43 & 5.65 & 8.09 \\
\hline UK & & $10.89(1951)$ & $6.67(1981)$ & 13.88 \\
\hline US & 18.40 & 15.88 & 10.67 & 20.2 \\
\hline
\end{tabular}

Source: World Inequality Database. http://wid.world/.

\section{The Impact of Neoliberalism on Inequality in the Anglophone Countries}

The precise impact of neoliberalism on inequality in the Anglophone countries is hard to measure, given the variety of factors which have affected changes in income and wealth in these countries, and elsewhere in the world. That said, inequality has risen more strongly in these countries than in other industrialized nations, and the evidence provided by the "varieties of capitalism" literature indicates that these Englishspeaking countries have implemented neoliberalism more strongly than other developed nations, consolidating their nature as "liberal market economies". This section briefly reviews the concept of neoliberalism, how the strengthening of market forces and transactions-based economic relationships have contributed to the specific form of capitalism prevalent in these countries today, and what forces have driven greater inequality.

\section{The concept of neoliberalism}

Neoliberalism is a concept that is broad and widely-used to describe the trend in public policies which emerged from the 1970s onwards, and that have accompanied the process of globalization. These policies have narrowed the scope of government intervention in developed and developing economies, while weakening the power of organized labor in pursuing wage claims and protecting workers' rights. The policies include specifically: the deregulation of markets; the shift away from fiscal policy as a tool for managing demand and supporting employment in favor of monetary policy aimed primarily at achieving price stability; the privatization and contacting out of public services; steep tax cuts for top income earners and the shift to regressive taxation (like VAT and sales taxes); ongoing cuts in corporation tax and the financing of public deficits through the sale of bonds to private and institutional investors; the pursuit of international trade liberalization; domestic and international capital market liberalization, and more generally the financialization of economic activity (i.e. the expansion of financial services and the transformation of assets into securities and financial instruments); as well as the deliberate weakening of trade union power, through anti-union legislation and cuts in numbers of tenured public sector workers.

To be sure, these processes have not been uniform across countries. As Jamie Peck notes, neoliberalism has taken a "zigzagging course": its path has been strewn with "policy failures, oppositional pushbacks, and stuttering forms of malregulation". He also rightly points out that in many countries total government spending has not much 
declined as a share of GDP, the State's powers have been extended in certain areas, and more generally that markets have always needed the State to enforce the protection of private property and contracts. Yet Peck also describes how neoliberalism as the dominant economic ideology and practice reasserted itself fairly quickly after the financial crisis (Peck 2013). Similarly, David Harvey has argued that neoliberalism has benefitted from the "uneven geographical developments" of nations, noting that "competition between territories (states, regions, or cities) as to who had the best model for economic development or the best business climate... heightened in the more fluid and open systems of trading relations established after 1970" (Harvey 2005: 87). Harvey too is skeptical about "extract(ing) some composite picture of a typical neoliberal state", yet he notes there are two arenas in particular in which neoliberalism restores class power. The first concerns the way labor and the environment are treated as mere commodities, to be subordinated to business interests. The second stems from how neoliberal states favor the financial system over the well-being of their populations and environments (ibid: 70-1): an observation he made in the mid-2000, shortly before the financial crisis and which has turned out to be highly prescient. Moreover, Harvey points to the privatization of assets as key component of neoliberal agenda, and the imperative of States to use their power to impose or invent market mechanisms (ibid: 65). Significantly, he observes that the main "substantive achievement of neoliberalization" has been to redistribute, rather than generate wealth and income (ibid: 159). This rapacious nature of neoliberalism is laid bare in even starker terms by Naomi Klein. In The Shock Doctrine, she argues that "disaster capitalism" emerged in the 1970s as a comprehensive policy approach to restructuring societies in states of disaster and shock, following: violent political takeover (Chile under Pinochet in the 1970s), internal collapse (the Soviet Union and its satellites in Eastern Europe in the early 1990s), invasion (Iraq in 2003) or natural disasters (hurricane Katrina in New Orleans, in 2005). Preying on profound societal disorientation associated with such upheavals, private interests restructured economies and societies for their own profit. This was (and is) achieved by drawing not only on neoliberal theory and policy-prescriptions, but also on techniques of psychiatry (including electro-shocks) experimented in the 1950s to remodel troubled personalities. Such policies were pursued very visibly in the aptly named, pro-market "shock therapies" applied to the transition economies of Eastern Europe during the early 1990s (Klein 2008).

Returning to the Anglophone countries, a considerable heterodox economic literature developed during the 1990s and through to the mid-2000s, examining their political and economic trajectories, in contrast to developments in other industrialized countries. In 1990, the Danish sociologist Gøsta Esping-Andersen published his landmark study on The Three Worlds of Welfare Capitalism, in which he identifies so-called "liberal welfare states". These are found in the English-speaking countries, and are characterized by minimal public social insurance (unemployment support, pensions, etc.), and incentives for households to subscribe to private health, pension and even unemployment schemes. A year later and very much in the wake of the fall of the Berlin Wall, Michel Albert (a senior civil servant turned insurance financier) contrasted what he called "neo-American capitalism" and "Rhineland capitalism", in Capitalisme contre capitalism (1991). Albert specifically pointed to the deepening of stock market finance for firms and the rise of shareholder capitalism in the 1980s, allied to tax cuts, deregulation and high military spending as characteristics of the new economic regime 
established by the Republican Presidency of Ronald Reagan (January 1981 to January 1989). In contrast, Rhineland capitalism - exemplified most clearly by (West) Germany - was based on stable relationships between companies and their "house banks", as well as more stable relationships between firms, their suppliers, their customers and their employees. Indeed, a notable feature of Rhineland capitalism has been the involvement of companies in training apprentices and the negotiation of collective branch agreements between employer organizations and unions. This dichotomy of models of capitalism was extended in the collective research project and publication coordinated by Peter Hall and David Soskice: Varieties of Capitalism: The Institutional Foundations of Comparative Advantage (2001). By investigating the functioning of companies in a series of economic sectors, the study argues that a basic distinction can be made between "liberal market economies" (LMEs) and "coordinated market economies" (CMEs) in terms of five relational spheres: industrial relations, vocational training and education, corporate governance, inter-firm relations and employees. Although nuances exist, the Anglophone economies are all identified as LMEs, characterized by much clearer transaction and market-based relationships than CMEs. Two distinguishing characteristics of these countries involve the way the financial rewards of higher education grew during the 1980s and 1990s, while their educational systems produced quite large minorities of workers with relatively limited skills, even if overall educational levels were comparatively high.

In fact, the evolution of wages for low-skilled workers has been widely noted as a cause for inequality in the economic literature. In a recent, summary article of global inequality trends, François Bourguignon notes that "almost by definition, globalization and technological progress are the most obvious common factors of income distribution across countries", and that "[i]n the developed countries, globalization and skill-based technological progress are certainly responsible for a rise in the share of total income going to capital and for the slow growth of wages and employment of unskilled labor" (Bourguignon 2017). For much of the 1980s and 1990s, technological progress was strongly identified as the main source of rising inequality in the United States especially, due to skills differentials. Yet with the rise of Chinese exports, trade competition has played a more important role too. This follows almost mechanically as indicated by the theory of international economics - from the way greater international trade favors the returns on capital as a production factor in rich countries, either directly or through the geographical relocation of manufacturing via foreign direct investment or outsourcing to low-wage countries. The financialization accompanying globalization has further enhanced rewards to capital, including investment income received by high-income households (specifically of top executives and leading employees/managers in finance). More specifically, Bourguignon quotes an OECD study published in 2011 which estimated that - on average - globalization and technological change explained 40 percent of the increase in the Gini coefficient since the early 1980s. A further 22 percent of the average increase was due to assortative mating and changing household composition. Furthermore, among the country-specific factors aggravating inequality, changes in tax and welfare systems have had the most direct impact on inequality (Bourguignon 2017). 


\section{Policy shifts}

28 in the Anglophone countries. It is now often forgotten that both the UK and the US were high-tax countries in the decades after World War II, compared for example to France and Germany. The top income tax rate in Britain in the 1970s was 83 percent, and in the US it was 70 percent. Substantial tax cuts by the Thatcher and Reagan governments then brought the top income tax rates down to 40 percent in the UK and to 28 percent in the US by 1988, whereas the rates in Germany (56 percent) and France (57 percent) remained much higher at the time. ${ }^{5}$ At the beginning of 2018, the top personal income tax rates were 37 percent in the US, ${ }^{6} 45$ percent in the UK, ${ }^{7} 53$ percent in France, ${ }^{8}$ and 42 percent in Germany. ${ }^{9}$ These figures indicate both a spread of neoliberalism's anti-tax policies, yet also continued divergence among countries. Proposition 13 to cut property taxes in 1978. In the United States, such tax cutting subsequently became part of the "supply-side" agenda to break with the economic policies of the past, and which was frequently referred to as "Reaganomics" after Reagan's election in 1980. This agenda involved market deregulation, but also the clear belief that tax cuts would stimulate economic activity and ultimately lead to higher overall tax revenues, a relationship promoted publicly and visually by Arthur Laffer and his "Laffer-curve" (Laffer 2004). Allied to the idea that tax cuts would lead to faster growth and higher tax revenues was the belief that greater wealth (of the rich) would "trickle down" to the rest of society. Everyone would finally be better off. While the economics of Thatcherism were not couched in exactly the same terms, the policies of successive British governments (first Conservative, then New Labour) were based on similar beliefs: for the Conservatives, cutting taxes would encourage people to work more and build businesses; for New Labour, strong growth - including the success of financial services - would provide the tax revenues to fight child poverty and pay tax credits for low-income families. The same is broadly true wherever neoliberal reforms have been implemented, especially in the Anglophone world. Thus, the mid-1980s saw fundamental shifts to neoliberal economic policies in Australia and New Zealand pushed through by Labor governments elected in both countries in 1984. In Australia, reforms began by liberalizing international trade through lower tariffs, the removal of exchange controls and the floating of the exchange. The neoliberal agenda was then pursued incrementally, throughout the following two decades, affecting all aspects of the economy (De Brouwer 2003). In New Zealand, reform was led especially by Finance Minister Roger Douglas who implemented a draconian, rapid neoliberal program of market deregulation and tax reform, dubbed "Rogernomics". Subsidies to agriculture (and industry) were scrapped, as were tariffs, while the top tax rate was gradually brought down from $66 \%$ to $33 \%$. A second sharp wave of reforms to deregulate markets was subsequently driven through by Ruth Richardson, Finance minister in the National government of 1990 to 1993, whose policies became known as "Ruthanasia" (Evans 1996). In Canada, reform came later and was pushed mainly to rein in public deficits and public debt by cutting taxes and decentralizing spending to Canada's provinces. As a result of massive fiscal restructuring, the overall government deficit was cut from $6 \%$ of GDP in 1995, to a balanced position by 1997, with surpluses thereafter, leading to significant downsizing of government and strong pay restraint (Thiessen 2001). 
30 By contrast, the policy shift in Ireland was more complex and intriguing. While pursuing a tax-cutting agenda in the late 1980s, tripartite coordination with management and unions also allowed the authorities to tackle inflation by using an incomes policy as part of a national development plan. This, together with Ireland's increasing integration into the European Union and the inflow of EU monies, paved the way for Ireland to become the Celtic Tiger in the 1990s. At the same time, the rockbottom corporate tax rate of only $12.5 \%$ helped lure substantial US high-tech investment to the country (Whelan 2013).

\section{Forces driving inequality}

31 While the dislocations of neoliberal reforms in the Anglophone world during the 1980s did not bring immediate clear improvements in their economic performance, the situation changed quite notably from the early 1990s onwards, through to the financial crisis of 2007-2008. This was a period of long, sustained growth on the whole. Even the stock market crash of high-tech companies in 2000, followed by conventional falls in stocks in the wake of 9/11 and a shallow recession in the US in 2001 did not upset this broadly buoyant picture. These were the heyday years of the Anglo-Saxon economic model, with even an American "liberal" (i.e. progressive) economist like Paul Krugman celebrating the "certain je ne sais quoi of les Anglophones" (Krugman 1999). What was less apparent at the time, however, was the way prosperity in these countries, and especially the United States, was dependent on household borrowing and rising property prices. Put simply, financial deregulation had allowed middle-income households in the United States, in particular, to "eat credit" in order to maintain their living standards, while their real wages stagnated (Rajan). When the crash came, the reality of neoliberalism for "middle America" was brutally revealed.

More fundamentally, the historical reality of capitalism was subsequently revealed to the US economics profession with the publishing of Thomas Piketty's seminal work in English in 2014, Capital in the Twenty-First Century. While this mammoth investigation into the long-term dynamics of capitalism had received some media attention in France, the release of the book in English in spring 2014 turned it into an international bestseller, with sales topping 1.5 million. Apart from its dazzling assembly of data, the central thesis of the book is that when operating normally, capitalism inevitably leads to greater inequality, especially of wealth. This proposition was supported by rigorous reasoning and long-term trend analyses conducted by Piketty (and his team) which led to the spectacularly simple conclusion that the real rate of return on capital $(r)$ generally exceeds the growth rate (g): or in a formula which anyone can understand $r>$ g. Other things being equal, capital in the hands of the few - including non-working rentiers - will therefore accumulate at a faster rate than growth and so lead to ever greater inequality. Moreover, Piketty argues that in periods of high capital values relative to labor income, the tendency for capital to concentrate is especially strong. This was the case in the $19^{\text {th }}$ century, as it is again true today, with high real-estate values in much of the developed world, and high stock market values: Graph 1 shows the rising share of total wealth held by the top $1 \%$, especially in the United States, and the typical U-shaped evolution of inequality measures during the $20^{\text {th }}$ century. As the world was still reeling from the financial crisis, Piketty's analysis clearly hit its mark. 
Graph 1: The Share Net Personal Wealth Held by the Top 1\% (in percent)

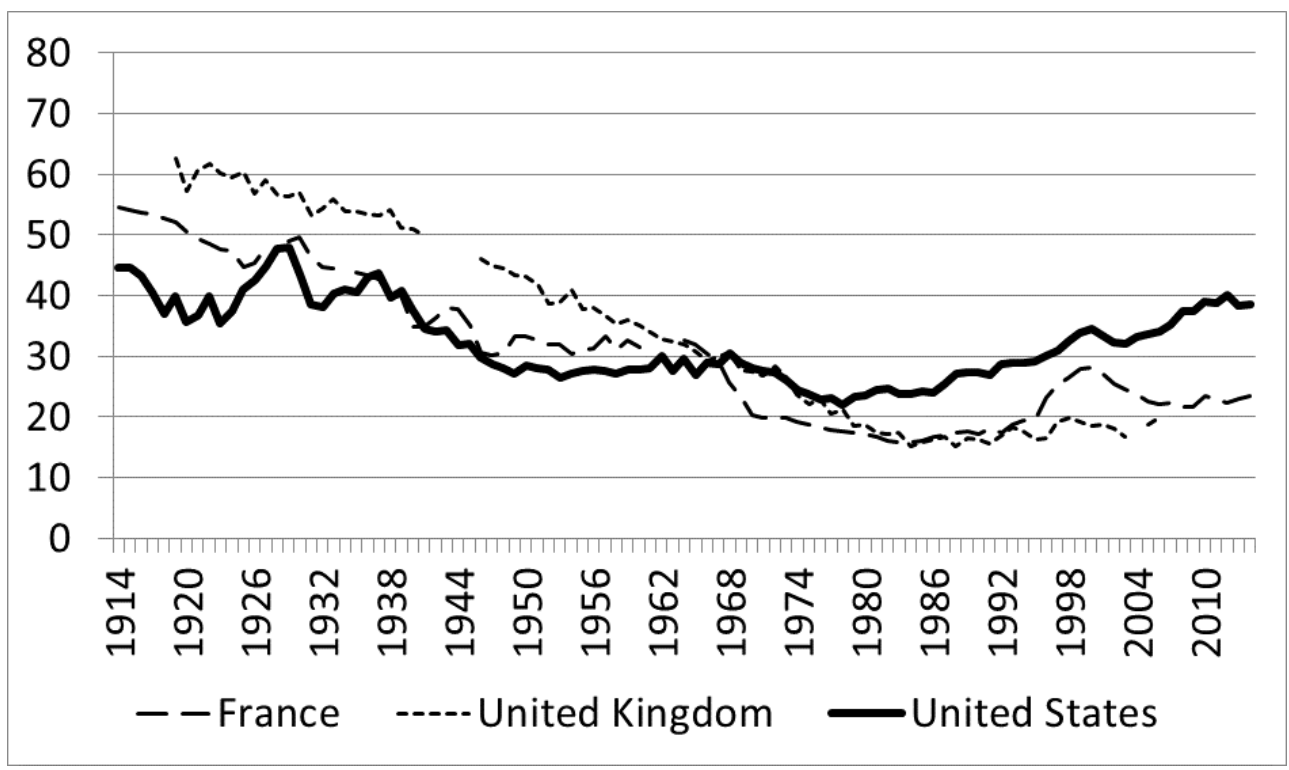

Source: World Inequality Database. http://wid.world/.

Piketty's book therefore explicitly overturned the previously held belief that while capitalism and industrialization had indeed led to a massive rise of inequality in the $19^{\text {th }}$ century, the $20^{\text {th }}$ century had experienced falling inequality, especially in the industrialized nations, but also elsewhere. This apparent behavior of capitalism was first identified by the economic historian Simon Kuznets, and became known as the "Kuznets curve", a bell-shaped curve in which inequality first rises over time, before subsequently falling. Piketty points out that Kuznets himself was aware that this optimistic outcome of capitalism was partly empirical and largely speculative. In fact, Piketty argues that the substantial reduction in inequality for much of the $20^{\text {th }}$ century had nothing to do with the internal workings of capitalism. Instead, it resulted from the political shocks of the World Wars and the economic consequences of the Great Depression. These unusual events led to massive falls in the value of accumulated capital relative to the output of labor, and hence to falls in the returns on capital relative to wages. Since the end of the 1970s, however, the slow post-1945 build-up of capital, along with the liberalization of markets and especially financial markets, have allowed the historical tendencies of capitalism to reassert themselves. As a result, inequality is once again rising. The explosion of pay for top managers, which today combines salaried income with earnings related to stock price movements, is a notable driver of the present surge in inequality (Piketty 2014: 30-61). This phenomenon has been especially marked in the Anglophone world, notably the United States and the United Kingdom. In both these countries, top managers' overall compensation has exploded from being twenty or thirty times average workers' pay in the 1960s and 1970s, to anything up to 200 or 300 times workers' pay today (Davis and Mishel 2014).

\section{Conclusion}

Neoliberalism has been a global phenomenon. It emerged first, most clearly in the United States and the United Kingdom in the late 1970s, coincidentally at a time when Deng Xiaoping began initiating market-oriented reforms in China. As time went on, and 
especially following the fall of the Berlin Wall in 1989 and the collapse of Soviet central planning as an alternative economic system, neoliberal policies have been adopted in many parts of the world. In the developed world, neoliberal reforms have generally been strongly pursued in the Anglophone nations, and these countries have all been clearly identified as "liberal market economies" in the varieties of capitalism literature. One consequence of their stronger pursuit of neoliberalism has been the rise in inequality observed since 1980 (although Ireland is a notable exception, as its history of tripartism has likely fostered greater social cohesion, so that its level of disposable income inequality has remained unchanged). The United States on the other hand stands out as its levels of income and wealth inequality have soared since the late 1970s. Given that the US makes up 70\% of the population of the Anglophone world studied in this paper, its experience largely dominates this country group. But it is important not to lose sight of the fact that, while all these countries today have higher levels of inequality than the OECD average (on the basis of Gini coefficients of their disposable household incomes), their experiences are varied.

\section{BIBLIOGRAPHY}

ACOSS (Australian Council of Social Service) and SPRC (Social Policy Research Centre). "Poverty in Australia 2016." 2016. https://www.acoss.org.au/wp-content/uploads/2016/10/Poverty-inAustralia-2016.pdf

Albert, Michel. Capitalisme contre capitalisme, Paris: Seuil, 1991.

Bourguignon, François. "World changes in inequality: an overview of facts, causes, consequences and policies.” Monetary and Economic Department. BIS Working Papers, № 654, August 2017.

Citro, Constance and Michael, Roberts ed. Measuring Poverty: A New Approach, Washington, DC: National Research Council, 1995.

Davis, Alyssa and Mishel, Lawrence. CEO Pay Continues to Rise as Typical Workers are Paid Less. Economic Policy Institute, 2014. https://www.epi.org/publication/ceo-pay-continues-to-rise/.

De Brouwer, Gordon. "Economic Reform and Growth in Australia", Paper prepared for the Australian Studies Association of Japan Symposium in Nagoya, 2003.

Department of Employment Affairs and Social Protection. Poverty: Measurement and Monitoring. 2016. https://m.welfare.ie/en/Pages/Poverty-Measurement-and-Monitoring.aspx.

Department of Work and Pensions. Households Below Average Income: An analysis of the UK income distribution: 1994/95-2016/17. https://www.gov.uk/government/uploads/system/uploads/ attachment_data/file/691917/households-below-average-income-1994-1995-2016-2017.pdf.

Esping-Andersen, Gøsta. The Three Worlds of Welfare Capitalism. Cambridge: Polity Press \& Princeton: Princeton UP, 1990.

European Anti Poverty Network Ireland. Relative Poverty Rates. https://www.eapn.ie/poverty/ relative-poverty-rates/. 
Evans, Lewis et al. "Economic Reform in New Zealand 1984-95: The Pursuit of Efficiency.” Journal of Economic Literature, XXXIV, 1996: 1856-1902.

Gamble, Andrew. “Governing in the New Hard Times." L'Observatoire de la société britannique 19, 2017: 31-47.

GOV.UK. "Income Tax rates and Personal Allowances." https://www.gov.uk/income-tax-rates. Government of Canada. “A Backgrounder on Poverty in Canada.” 2016. https://www.canada.ca/ en/employment-social-development/programs/poverty-reduction/backgrounder.html.

Hall, Peter and Soskice, David ed. Varieties of Capitalism. The Institutional Foundations of Comparative Advantage. Oxford: Oxford UP, 2001.

Harvey, David. A Brief History of Neoliberalism. Oxford: OUP, 2005.

Klein, Naomi. The Shock Doctrine: The Rise of Disaster Capitalism. London: Penguin, 2008.

Krugman, Paul. "That certain je ne sais quoi of les Anglophones." 1999. http://web.mit.edu/ krugman/www/english.html.

Laffer, Arthur. The Laffer Curve: Past, Present, and Future. The Heritage Foundation, 2004. https:// www.heritage.org/taxes/report/the-laffer-curve-past-present-and-future.

McGuinness, Feargal, "Poverty in the UK: statistics." House of Commons Library: Briefing Paper 7096, 2018. http://researchbriefings.parliament.uk/ResearchBriefing/Summary/ SN07096\#fullreport.

Melbourne Institute. “Poverty Lines: Australia, September Quarter 2017.” 2018.https:// melbourneinstitute.unimelb.edu.au/_ddata/assets/pdf_file/0006/2688099/Poverty-LinesAustralia-September-2017.pdf.

Milanovic, Branko. Global Inequality: a New Approach for the Age of Globalization, Cambridge, Massachusetts: Belknap Harvard, 2016.

Ministry of Social Development. "Household incomes in New Zealand: Trends in indicators of inequality and hardship 1982 to 2016." Wellington: 2017. https://www.msd.govt.nz/documents/ about-msd-and-our-work/publications-resources/monitoring/household-income-report/ 2017/2017-incomes-report-wed-19-july-2017.pdf.

Peck, Jamie. “Explaining (with) Neoliberalism.” Territory, Politics, Governance 1 (2), 2013. DOI: $10.1080 / 21622671.2013 .785365$

Piketty, Thomas. Le capital au XXIe siècle. Paris: Seuil, 2013.

Piketty, Thomas. Capital in the Twenty-First Century. Cambridge: Harvard UP, 2014.

Rajan, Raghuram. Fault Lines: How Hidden Fractures Still Threaten the World Economy. Princeton: Princeton UP, 2011.

Scheidel, Walter. The Great Leveler: Violence and the History of Inequality from the Stone Age to the Twenty-First Century. Princeton: Princeton UP, 2017.

Semega, Jessica L., Kayla R. Fontenot and Melissa A. Kollar. Income and Poverty in the United States: 2016. Washington, DC: U.S. Government Printing Office, 2017. https://www.census.gov/library/ publications/2017/demo/p60-259.html.

Statistics Canada. "Census in Brief: Children living in low-income households." http:// www12.statcan.gc.ca/census-recensement/2016/as-sa/98-200-x/2016012/98-200-x2016012eng.cfm. 
Steuerklassen.com. "Spitzensteuersatz." https://www.steuerklassen.com/steuern/ spitzensteuersatz/.

Thiessen, Gordon. “Canada's Economic Future: What Have We Learned from the 1990s?" Canadian Club of Toronto, 2001. https://www.bankofcanada.ca/2001/01/canada-economic-future-whathave-we-learned/.

Trading Economics. “United States Personal Income Tax Rate.” https://tradingeconomics.com/ united-states/personal-income-tax-rate.

United States Census Bureau. "Poverty Thresholds.” https://www.census.gov/data/tables/timeseries/demo/income-poverty/historical-poverty-thresholds.html.

Whelan, Karl. "Ireland's Economic Crisis: The Good, the Bad and the Ugly." University College Dublin, 2013. http://www.karlwhelan.com/Papers/Whelan-IrelandPaper-June2013.pdf.

Wikipedia. "Barème de l'impôt sur le revenu en France." https://fr.wikipedia.org/wiki/ Bar\%C3\%A8mes_de_l\%27imp\%C3\%B4t_sur_le_revenu_en_France.

World Inequality Database. URL: http://wid.world/.

\section{NOTES}

1. Both Thomas Piketty in his book (2013) and the WID (http://wid.world/) credit a large team for creating this database, including the WID Executive Committee of Facundo Alvaredo, Lucas Chancel, Piketty himself, Emmanuel Saez and Gabriel Zucman, and the late Anthony Atkinson.

2. For the OECD, the standard household of two adults is given a weight of 1 ( 0.67 for the first adult and 0.33 for the second adult). Children are then each weighted 0.2 , so that a household with two adults and two children has a weighting, or equivalence value, of 1.4.

3. *The conversion into euros has been done using exchange rates prevailing in early April 2018. These rates differ from those prevailing in the years indicated. Nor do they reflect purchasing power parity. The calculations just serve to give a rough indication of the euro equivalent of the values in the other currencies.

4. The Gini coefficients for 1980 are taken from Walter Scheidel (2017: 406-8). The figures in brackets indicate other years of available data (e.g., $(84)=1984)$.

5. The figures here are taken from Thomas Piketty, ibid, Chapter 14. They can all be downloaded from his webpages at the Paris School of Economics. http://piketty.pse.ens.fr/fr/capital21c.

6. Trading Economics. "United States Personal Income Tax Rate." https:// tradingeconomics.com/united-states/personal-income-tax-rate.

7. GOV.UK. "Income Tax rates and Personal Allowances." https://www.gov.uk/income-tax-rates.

8. 45 percent top income tax rate plus the 8 percent CSG. Wikipedia. "Barème de l'impôt sur le revenu en France”. https://fr.m.wikipedia.org/wiki/ Bar\%C3\%A8mes_de_l\%27imp\%C3\%B4t_sur_le_revenu_en_France.

9. Steuerklassen.com. "Spitzensteuersatz", https://www.steuerklassen.com/steuern/ spitzensteuersatz/. 


\section{ABSTRACTS}

This article reviews the evolution of inequality and poverty in the Anglophone countries (the United States, the United Kingdom, Canada, Australia, New Zealand and Ireland) since the shift to neoliberal economic policies in the late 1970s. It provides brief summaries of the key definitions of inequality and poverty, which are separate but related phenomena. The article confirms the general impression that inequality has risen more quickly in this country group than in other developed countries. This is especially so for the United States, although Ireland is a notable exception with unchanged inequality levels. The article goes on to identify key policy characteristics of neoliberalism which have favoured capital over labour, and how they have contributed to consolidating the economic structure of these countries as "liberal market economies". This in turn has impacted inequality, especially through strong cuts in top income tax rates.

Cet article examine l'évolution de l'inégalité et de la pauvreté dans les pays anglophones (ÉtatsUnis, Royaume-Uni, Canada, Australie, Nouvelle-Zélande et Irlande) depuis la mise en place des politiques économiques néolibérales à partir de la fin des années 1970. Il donne un bref résumé des définitions clés de l'inégalité et de la pauvreté, qui sont des phénomènes distincts mais liés. L'article confirme l'impression générale selon laquelle les inégalités ont augmenté plus rapidement dans ce groupe de pays que dans d'autres pays développés. C'est particulièrement le cas pour les États-Unis. L'Irlande constitue à l'inverse une exception notable, avec des niveaux d'inégalité inchangés. L'article poursuit en identifiant les principales caractéristiques politiques du néolibéralisme qui ont favorisé le capital au détriment du travail et comment elles ont contribué à consolider la structure économique de ces pays en tant qu'"économies de marché libérales". Ceci a eu un impact sur les inégalités, particulièrement par le biais de fortes réductions d'impôts pour les tranches supérieures.

\section{INDEX}

Keywords: neoliberalism, globalization, taxation, inequality, poverty

Mots-clés: mondialisation, néolibéralisme, fiscalité, inégalité, pauvreté

\section{AUTHOR}

\section{NICHOLAS SOWELS}

Nicholas Sowels is Associate Professor in English for economics at the Paris 1 Panthéon-Sorbonne University since 2003. His research in recent years has focused on the causes and consequences of the 2007-2008 financial crisis, the financial implications of Brexit, as well as other issues related to the British economy and public policy. Contact: nicholas.sowels[at]univ-paris1.fr 